\title{
Membrane Reactor for Methanol Synthesis Using Si-Rich LTA Zeolite Membrane
}

\author{
Masahiro Seshimo ${ }^{1, *}$, Bo Liu ${ }^{1,+}{ }^{\circledR}$, Hey Ryeon Lee ${ }^{1}$, Katsunori Yogo ${ }^{1}$, Yuichiro Yamaguchi ${ }^{1, \ddagger}$, \\ Nobuyuki Shigaki ${ }^{2}$, Yasuhiro Mogi ${ }^{2}$, Hidetoshi Kita ${ }^{1,3}$ and Shin-ichi Nakao ${ }^{1}$
}

1 Inorganic Membranes Research Center, Research Institute of Innovative Technology for the Earth (RITE), 1-7 Hikaridai, Seika-cho, Souraku-gun, Kyoto 619-0237, Japan; liu@njtech.edu.cn (B.L.); hr3638@naver.com (H.R.L.); yogo@rite.or.jp (K.Y.); yamaguti@osakagas.co.jp (Y.Y.); kita@yamaguchi-u.ac.jp (H.K.); nakao@rite.or.jp (S.-i.N.)

2 Steel Research Laboratry, JFE Steel Corporation, 1 Kokan-cho, Fukuyama 721-8510, Japan; n-shigaki@jfe-steel.co.jp (N.S.); y-mogi@jfe-steel.co.jp (Y.M.)

3 Environmental Science and Engineering, Graduate School of Sciences and Technology for Innovation, Yamaguchi University, 2-16-1 Tokiwadai, Ube 755-8611, Japan

* Correspondence: seshimo@rite.or.jp; Tel.: +81-774-95-5086

+ Present address: State Key Laboratory of Materials-Oriented Chemical Engineering, College of Chemical Engineering, Nanjing Tech University, Nanjing 210009, China.

$\ddagger$ Present address: Energy Solution Business Unit, Administration Department, Osaka Gas Co., Ltd., 4-1-2 Hiranomachi, Chuo-ku, Osaka 541-0046, Japan.

Citation: Seshimo, M.; Liu, B.; Lee, H.R.; Yogo, K.; Yamaguchi, Y.; Shigaki, N.; Mogi, Y.; Kita, H.; Nakao, S.-i. Membrane Reactor for Methanol Synthesis Using Si-Rich LTA Zeolite Membrane. Membranes 2021, 11, 505. https://doi.org/10.3390/membranes 11070505

Academic Editor: Hannes Richter

Received: 3 June 2021

Accepted: 29 June 2021

Published: 30 June 2021

Publisher's Note: MDPI stays neutral with regard to jurisdictional claims in published maps and institutional affiliations.

Copyright: (C) 2021 by the authors. Licensee MDPI, Basel, Switzerland. This article is an open access article distributed under the terms and conditions of the Creative Commons Attribution (CC BY) license (https:/ / creativecommons.org/licenses/by/ $4.0 /)$.

\begin{abstract}
We successfully demonstrated the effect of a membrane reactor for methanol synthesis to improve one-pass $\mathrm{CO}_{2}$ conversion. An Si-rich LTA membrane for dehydration from a methanol synthesis reaction field was synthesized by the seed-assisted hydrothermal synthesis method. The $\mathrm{H}_{2} \mathrm{O}$ permselective performance of the membrane showed $1.5 \times 10^{-6} \mathrm{~mol} \mathrm{~m}^{-2} \mathrm{~s}^{-1} \mathrm{~Pa}^{-1}$ as $\mathrm{H}_{2} \mathrm{O}$ permeance and around 2000 as selectivity of $\mathrm{H}_{2} \mathrm{O} / \mathrm{MeOH}$ at $473 \mathrm{~K}$. From the results of membrane reactor tests, the $\mathrm{CO}_{2}$ conversion of the membrane reactor was higher than that of the conventional packed-bed reactor under the all of experimental conditions. Especially, at $4 \mathrm{MPa}$ of reaction pressure, the conversion using the membrane reactor was around $60 \%$. In the case of using a packed-bed reactor, the conversion was $20 \%$ under the same conditions. In addition, the calculated and experimental conversion were in good agreement in both the case of the membrane reactor and packed-bed reactor.
\end{abstract}

Keywords: zeolite membrane; Si-rich LTA; methanol synthesis; membrane reactor

\section{Introduction}

Methanol $(\mathrm{MeOH})$ is an important chemical for acetic acid and formaldehyde synthesis. Generally, $\mathrm{MeOH}$ synthesis from syngas as $\mathrm{H}_{2}, \mathrm{CO}$, and $\mathrm{CO}_{2}$ mixture is performed at high temperature (473-573 $\mathrm{K}$ ) and high pressure (5-10 MPa) using $\mathrm{Cu} / \mathrm{ZnO}$ as a catalyst in the industrial process. However, there is an issue that the one-pass yield of $\mathrm{MeOH}$ shows a low value owing to the limitation of equilibrium. A membrane reactor using $\mathrm{MeOH}$ and/or $\mathrm{H}_{2} \mathrm{O}$ permselective membrane is expected to improve one-pass yield. Struis et al. studied $\mathrm{MeOH}$ and $\mathrm{H}_{2} \mathrm{O}$ permeation performance from $\mathrm{MeOH} / \mathrm{H}_{2}$ and $\mathrm{H}_{2} \mathrm{O} / \mathrm{H}_{2}$ mixtures through Nafion membranes for a $\mathrm{MeOH}$ synthesis membrane reactor [1,2]. Nafion membranes show relatively high separation performance at $473 \mathrm{~K}$. However, it is difficult to apply the membrane to a $\mathrm{MeOH}$ synthesis membrane reactor because of thermal stability and mechanical strength.

Inorganic membranes have thermal stability, chemical stability and mechanical strength. Pd-based [3,4], carbon [5,6], silica [7-9], and zeolite membranes are categorized as inorganic membranes. In particular, zeolite membranes have uniform micropores and selective adsorption, and their unique properties differ from that of other inorganic membranes. Zeolite membranes are often used for isomer separation owing to their uniform micropores [10-13]. Zeolite membranes can be used in the dehydration process, and several 
types of zeolite membranes such as LTA [14-16], MOR [17,18], and CHA [19-21] have been investigated for alcohol dehydration owing to their hydrophilic nature. In addition, LTA and CHA-types zeolite membranes with high performance for separation of alcohol/water mixture have been developed and commercialized. The LTA-type zeolite membranes show relatively high $\mathrm{H}_{2} \mathrm{O}$ flux compared with other types of zeolite membrane because theSi / $\mathrm{Al}$ ratio is 1 . Okamoto and his co-workers reported that $\mathrm{H}_{2} \mathrm{O}$ flux through an LTA membrane was $3.5 \mathrm{~kg} \mathrm{~m}^{-2} \mathrm{~h}^{-1}$ at $378 \mathrm{~K}$ under water/methanol mixture conditions [14]. However, in generally, LTA membranes are difficult to apply methanol synthesis because of their hydrothermal stability. On the other hand, MOR [17] and CHA [21] zeolite membranes are expected to have high hydrothermal stability, however, $\mathrm{H}_{2} \mathrm{O}$ permeance is low to compared with LTA membranes. When inorganic membranes are applied to a membrane reactor for methanol synthesis, the membranes require high $\mathrm{H}_{2} \mathrm{O}$ and / or $\mathrm{MeOH}$ selective performance from $\mathrm{H}_{2} \mathrm{O}, \mathrm{MeOH}, \mathrm{CO}, \mathrm{CO}_{2}$, and $\mathrm{H}_{2}$ mixture with high $\mathrm{H}_{2} \mathrm{O}$ and / or $\mathrm{MeOH}$ flux to improve the one-pass $\mathrm{MeOH}$ yield. In the case of $\mathrm{MeOH}$ removal from the reaction system, $\mathrm{Na}^{+}$-exchange ZSM-5 (Na-ZSM-5) membranes indicate permselective performance of polar molecules, such as $\mathrm{H}_{2} \mathrm{O}$ and $\mathrm{MeOH}$, from the $\mathrm{MeOH} / \mathrm{H}_{2} \mathrm{O} / \mathrm{H}_{2}$ mixture in a relatively high temperature range [22]. Na-ZSM-5 membranes can be suitable for $\mathrm{MeOH}$ synthesis membrane reactors because Na cations, which are included in MFI-framework, have interaction with $\mathrm{MeOH}$ and $\mathrm{H}_{2} \mathrm{O}$. However, a membrane reactor for $\mathrm{MeOH}$ synthesis from $\mathrm{CO}_{2}$ as a raw material requires a distillation process to obtain high purity $\mathrm{MeOH}$, because both $\mathrm{MeOH}$ and $\mathrm{H}_{2} \mathrm{O}$ molecules can pass through that membrane. On the other hand, $\mathrm{H}_{2} \mathrm{O}$ permselective zeolite membranes that are applicable to the methanol synthesis membrane reactor have been developed and evaluated. Sawamura and his co-workers developed an MOR-type zeolite membrane and investigated the separation performance of the membrane under $\mathrm{H}_{2} \mathrm{O}-\mathrm{H}_{2}-\mathrm{MeOH}$ mixture conditions [23]. $\mathrm{H}_{2} \mathrm{O} / \mathrm{MeOH}$ permselective performance of the membrane showed a 73-101 of separation factor. Raso and his co-workers evaluated the $\mathrm{H}_{2} \mathrm{O}$ selective performance of several zeolite membranes such as LTA, T-type, CHA, and MOR under $\mathrm{H}_{2} \mathrm{O} / \mathrm{H}_{2} / \mathrm{CO}_{2}$ mixture conditions [24]. According to this work, LTA zeolite membranes showed the best $\mathrm{H}_{2} \mathrm{O} / \mathrm{H}_{2}$ separation performance for the methanol synthesis membrane reactor, and the $\mathrm{H}_{2} \mathrm{O}$ and $\mathrm{MeOH}$ permeances calculated from the exit gas composition of the membrane reactor were around $3.5 \times 10^{-8} \mathrm{~mol} \mathrm{~m}^{-2} \mathrm{~s}^{-1} \mathrm{~Pa}^{-1}$ and $1.5 \times 10^{-9} \mathrm{~mol} \mathrm{~m}^{-2} \mathrm{~s}^{-1} \mathrm{~Pa}^{-1}$, respectively.

To obtain high purity $\mathrm{MeOH}$ with a simple process, it is necessary to select a type of membrane reactor that extracts only $\mathrm{H}_{2} \mathrm{O}$ molecules, and the membrane requires high $\mathrm{H}_{2} \mathrm{O}$ permselective performance. Previously, we synthesized an Si-rich LTA-type zeolite membrane, which showed extremely high $\mathrm{H}_{2} \mathrm{O} / \mathrm{MeOH}$ permselective performance [25]. In addition, the Si-rich LTA membrane had hydrothermal stability. In this study, we developed a membrane reactor for $\mathrm{MeOH}$ synthesis using an Si-rich LTA zeolite membrane to improve one-pass conversion compared with a conventional packed-bed reactor. A simulation model was also constructed to investigate optimal reaction conditions and membrane performance.

\section{Materials and Methods}

\subsection{MeOH Synthesis Membrane Reactor Using an Si-Rich LTA Membrane}

The Si-rich LTA zeolite membrane was synthesized by the seed-assisted hydrothermal synthesis method. The Si-rich LTA seeds prepared from a synthesis gels with $3.9 \mathrm{Al}_{2} \mathrm{O}_{3}: 18 \mathrm{SiO}_{2}$ : $5 \mathrm{Na}_{2} \mathrm{O}: 173 \mathrm{H}_{2} \mathrm{O}$, as suggested in the literature by Conato et al. [26]. Obtained seeds were coated on the symmetric alumina tube by rubbing method. The seeded support was soaked into the synthesis gels with $0.21 \mathrm{Al}_{2} \mathrm{O}_{3}: \mathrm{SiO}_{2}: 0.27 \mathrm{Na}_{2} \mathrm{O}: 38 \mathrm{H}_{2} \mathrm{O}$. Details of the synthesis conditions and methods are shown elsewhere [25]. The surface of the obtained membrane was observed by SEM, and the $\mathrm{Si} / \mathrm{Al}$ ratio was measured by SEM-EDX (SU9000, Hitachi High-Tech Co., Tokyo, Japan). After membrane synthesis, vapor permeation performance of the membrane was evaluated under $\mathrm{H}_{2} \mathrm{O} / \mathrm{MeOH}$ mixture conditions. The $\mathrm{H}_{2} \mathrm{O} / \mathrm{MeOH}$ ratio 
was $10 / 90 \mathrm{wt} \%$ in vapor phase. The experimental apparatus was shown in our previous work [25]. $\mathrm{H}_{2} \mathrm{O}$ and $\mathrm{MeOH}$ flux were calculated using the following formula:

$$
J=\frac{m}{(A \times t)}
$$

Where $J, m, A$, and $t$ are flux $\left(\mathrm{kg} \mathrm{m}^{-2} \mathrm{~h}\right)$, permeate weight $(\mathrm{kg})$, the effective membrane area $\left(\mathrm{m}^{2}\right)$, and the measurement time $(\mathrm{h})$, respectively. The permeate vapor collected by the cold trap was injected into a GC-TCD (GC-4000 Plus, Shimadzu Co., Kyoto, Japan) for measurement of the $\mathrm{H}_{2} \mathrm{O} / \mathrm{MeOH}$ molar ratio.

The schematic diagram of the experimental apparatus for the $\mathrm{MeOH}$ synthesis membrane reactor is shown in Figure 1. $\mathrm{Cu} / \mathrm{ZnO}$ catalyst was used for $\mathrm{MeOH}$ synthesis and placed outside of the membrane. The catalyst particle size was around $500 \mu \mathrm{m}$. The inner diameter of the reactor was $22 \mathrm{~mm}$. The catalysts were conducted hydrogen reduction at $453 \mathrm{~K}$ under $\mathrm{H}_{2} / \mathrm{N}_{2}$ mixture condition overnight before the reaction tests. $\mathrm{CO}_{2}$ and $\mathrm{H}_{2}$ mixture gas, as raw material, was fed to the catalyst bed. The molar ratio of $\mathrm{H}_{2} / \mathrm{CO}_{2}$ was 3 , which is the same as the stoichiometric ratio. The generated $\mathrm{H}_{2} \mathrm{O}$ was through the membrane, which was placed at the center of the reactor, and flowed to the permeation side. The $\mathrm{CO}_{2}$ conversion was calculated from the concentrations of $\mathrm{CO}_{2}, \mathrm{H}_{2}, \mathrm{MeOH}$, and $\mathrm{H}_{2} \mathrm{O}$ in the retentate and permeate side. These concentrations were measured by gas chromatograph (GC-4000 Plus, Shimadzu Co., Kyoto, Japan). The membrane reactor tests were conducted under the following conditions: $453-493 \mathrm{~K}, 1-4 \mathrm{MPa}$, and SV = 200, $1000 \mathrm{~h}^{-1}$.

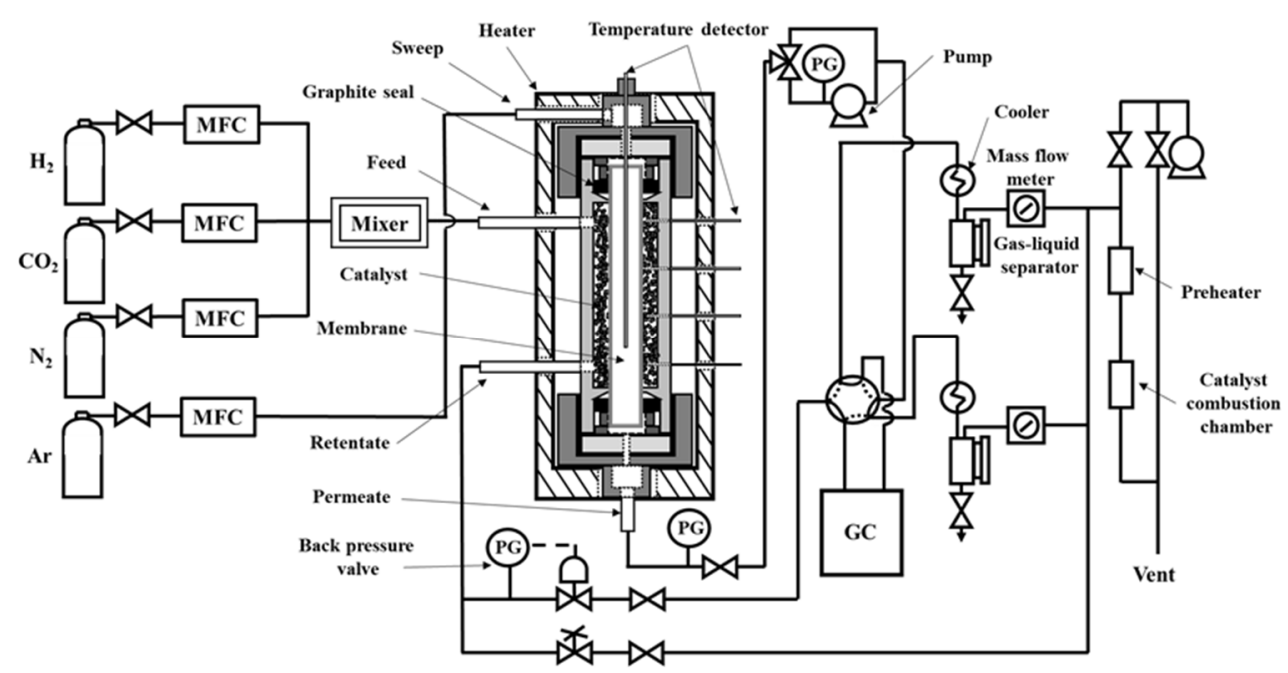

Figure 1. Schematic diagram of experimental apparatus for $\mathrm{MeOH}$ synthesis membrane reactor using an Si-rich LTA membrane.

\subsection{Simulation Model of Membrane Reactor for $\mathrm{MeOH}$ Synthesis}

The $\mathrm{MeOH}$ synthesis from the hydrogenation of $\mathrm{CO}$ and $\mathrm{CO}_{2}$ mixed gas consists of the following $\mathrm{CO}_{2}$ conversion (1), $\mathrm{CO}$ conversion (2), and reverse water gas shift reaction (3).

(1) $\mathrm{CO}_{2}+3 \mathrm{H}_{2} \rightleftarrows \mathrm{CH}_{3} \mathrm{OH}+\mathrm{H}_{2} \mathrm{O}$

(2) $\mathrm{CO}+2 \mathrm{H}_{2} \rightleftarrows \mathrm{CH}_{3} \mathrm{OH}$

$\Delta \mathrm{H}=-49.4 \mathrm{~kJ} / \mathrm{mol}$

(3) $\mathrm{CO}_{2}+\mathrm{H}_{2} \rightleftarrows \mathrm{CO}+\mathrm{H}_{2} \mathrm{O}$

$\Delta \mathrm{H}=-90.9 \mathrm{~kJ} / \mathrm{mol}$

$\Delta \mathrm{H}=41.5 \mathrm{~kJ} / \mathrm{mol}$

In this study, we constructed a membrane reactor simulation using the kinetic model proposed by Graaf and co-workers for low-pressure methanol synthesis on a $\mathrm{Cu} / \mathrm{ZnO} / \mathrm{Al}_{2} \mathrm{O}_{3}$ catalyst [27-29]. The correspondent rate expressions due to the hydrogenation of $\mathrm{CO}_{2}, \mathrm{CO}$, and the reverse water gas shift reaction are: 
$\mathrm{CO}_{2}$ conversion

$$
r_{\mathrm{D}}=\frac{k_{\mathrm{D}} K_{\mathrm{CO}_{2}}\left(f_{\mathrm{CO}_{2}} f_{\mathrm{H}_{2}}^{3 / 2}-f_{\mathrm{CH}_{3} \mathrm{OH}} f_{\mathrm{H}_{2} \mathrm{O}} /\left(f_{\mathrm{H}_{2}}^{3 / 2} K_{\mathrm{D}}^{0}\right)\right)}{\left(1+K_{\mathrm{CO}} f_{\mathrm{CO}}+K_{\mathrm{CO}_{2}} f_{\mathrm{CO}_{2}}\right)\left(f_{\mathrm{H}_{2}}^{1 / 2}+\left(K_{\mathrm{H}_{2} \mathrm{O}} / K_{\mathrm{H}_{2}}^{1 / 2}\right) f_{\mathrm{H}_{2} \mathrm{O}}\right)}
$$

CO conversion

$$
r_{\mathrm{M}}=\frac{k_{\mathrm{M}} K_{\mathrm{CO}}\left(f_{\mathrm{CO}} f_{\mathrm{H}_{2}}^{3 / 2}-f_{\mathrm{CH}_{3} \mathrm{OH}} /\left(f_{\mathrm{H}_{2}}^{1 / 2} K_{M}^{0}\right)\right)}{\left(1+K_{\mathrm{CO}} f_{\mathrm{CO}}+K_{\mathrm{CO}_{2}} f_{\mathrm{CO}_{2}}\right)\left(f_{\mathrm{H}_{2}}^{1 / 2}+\left(K_{\mathrm{H}_{2} \mathrm{O}} / K_{\mathrm{H}_{2}}^{1 / 2}\right) f_{\mathrm{H}_{2} \mathrm{O}}\right)}
$$

Reverse water gas shift reaction

$$
r_{\mathrm{R}}=\frac{k_{\mathrm{R}} K_{\mathrm{CO}_{2}}\left(f_{\mathrm{CO}_{2}} f_{\mathrm{H}_{2}}-f_{\mathrm{H}_{2} \mathrm{O}} f_{\mathrm{CO}} /\left(K_{\mathrm{R}}^{0}\right)\right)}{\left(1+K_{\mathrm{CO}} f_{\mathrm{CO}}+K_{\mathrm{CO}_{2}} f_{\mathrm{CO}_{2}}\right)\left(f_{\mathrm{H}_{2}}^{1 / 2}+\left(K_{\mathrm{H}_{2} \mathrm{O}} / K_{\mathrm{H}_{2}}^{1 / 2}\right) f_{\mathrm{H}_{2} \mathrm{O}}\right)}
$$

where $r_{\mathrm{D}}, r_{\mathrm{M}}, r_{\mathrm{R}}$ represent the reaction rate of hydrogenation of $\mathrm{CO}_{2}, \mathrm{CO}$, and reverse water gas shift, $k_{\mathrm{D}}, k_{\mathrm{M}}, k_{\mathrm{R}}$, the reaction rate constant, $K_{\mathrm{D}}, K_{\mathrm{M}}, K_{\mathrm{R}}$, the equilibrium constant, $K_{\mathrm{j}}$, the adsorption equilibrium constant of $\mathrm{j}$ component, and $f_{\mathrm{j}}$, fugacity. The equilibrium state between the reaction in the membrane reactor and $\mathrm{H}_{2} \mathrm{O}$ permeation was considered. We assumed plug flow, isothermal operation, and constant permselectivity, and calculated the reaction equilibrium, the permeation of $\mathrm{H}_{2} \mathrm{O}$, and the mass balance according to the membrane selectivity other than $\mathrm{H}_{2} \mathrm{O}$. In addition, this simulation model does not consider the concentration polarization of the reaction tube in the radial direction.

\section{Results and Discussion}

The Si / Al ratio of the Si-rich LTA membrane was around 1.5 measured by SEM-EDX, and was similar to our previous work [25]. To compare conventional LTA membranes $(\mathrm{Si} / \mathrm{Al}=1)$, the framework of the membrane had a relatively high Si content. Surface SEM images are shown in Figure 2, comparing with conventional LTA membranes. The particle size and the morphology consisted of an Si-rich zeolitic layer that was approximately the same as that which consisted of LTA. The temperature dependence of $\mathrm{H}_{2} \mathrm{O}$ permselective performance through the synthesized Si-rich LTA and conventional LTA membranes is shown in Figure 3. $\mathrm{H}_{2} \mathrm{O}$ permeances of both membranes were approximately constant regardless of temperature. On the other hand, $\mathrm{MeOH}$ permeances were increased with increasing temperature. It is considered that the permeation mechanism of this membrane is based on adsorption separation owing to its hydrophilic nature. Thus, in a relatively high temperature range, the amount of $\mathrm{H}_{2} \mathrm{O}$ absorbed into pores of the membrane decreases, with the effect of inhibiting the permeation of $\mathrm{MeOH}$, which becomes smaller. To compare between the permselective performance of the Si-rich LTA and LTA membranes, $\mathrm{H}_{2} \mathrm{O}$ permeance and $\mathrm{H}_{2} \mathrm{O} / \mathrm{MeOH}$ selectivity of Si-rich LTA was higher than those of LTA membrane. The Si content in the Si-rich LTA membrane was increased compared with that in conventional LTA membrane from SEM-EDX measurement. The compensating cation (Na cation in this study) that inhibits $\mathrm{H}_{2} \mathrm{O}$ permeation through zeolitic pores is slightly less than the LTA membrane. Therefore, $\mathrm{H}_{2} \mathrm{O}$ permeance of the Si-rich LTA membranes was improved. In addition, $\mathrm{H}_{2} \mathrm{O} / \mathrm{MeOH}$ selectivity of the Si-rich LTA membrane was also improved; thus, the hydrophilicity of the membrane was not significantly impaired. The Si-rich LTA membrane exhibited $1.5 \times 10^{-6} \mathrm{~mol} \mathrm{~m}^{-2} \mathrm{~s}^{-1} \mathrm{~Pa}^{-1}$ of $\mathrm{H}_{2} \mathrm{O}$ permeance, and around 2000 of selectivity $\left(\mathrm{H}_{2} \mathrm{O} / \mathrm{MeOH}\right)$ at $473 \mathrm{~K}$, thus, this membrane was applied to the membrane reactor for methanol synthesis. 

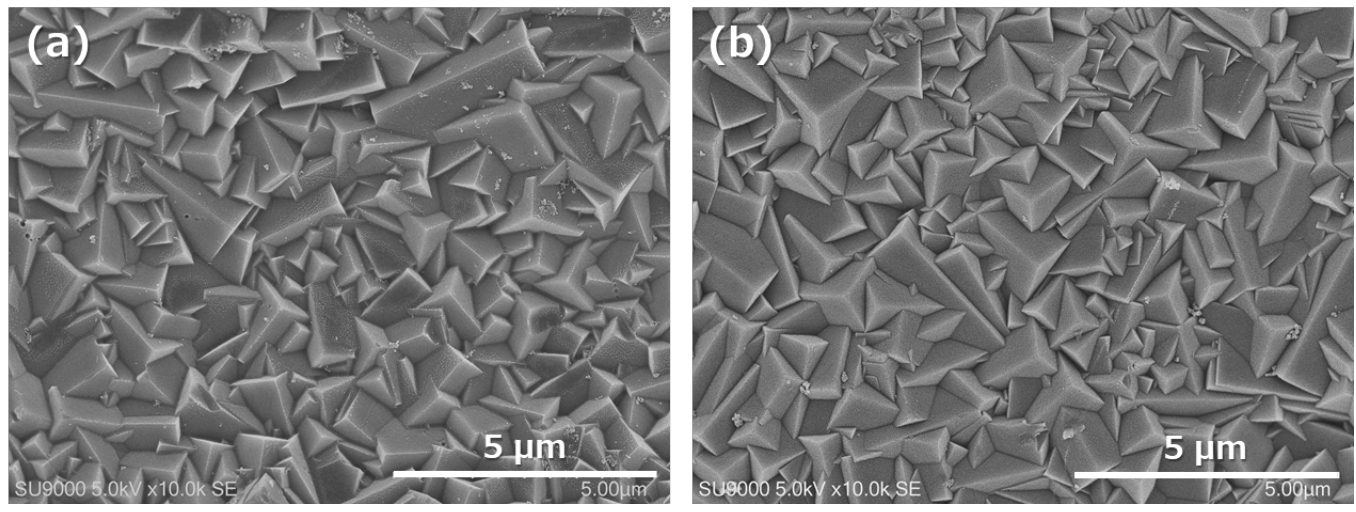

Figure 2. Surface SEM images of (a) the Si-rich LTA membrane and (b) conventional LTA membrane.

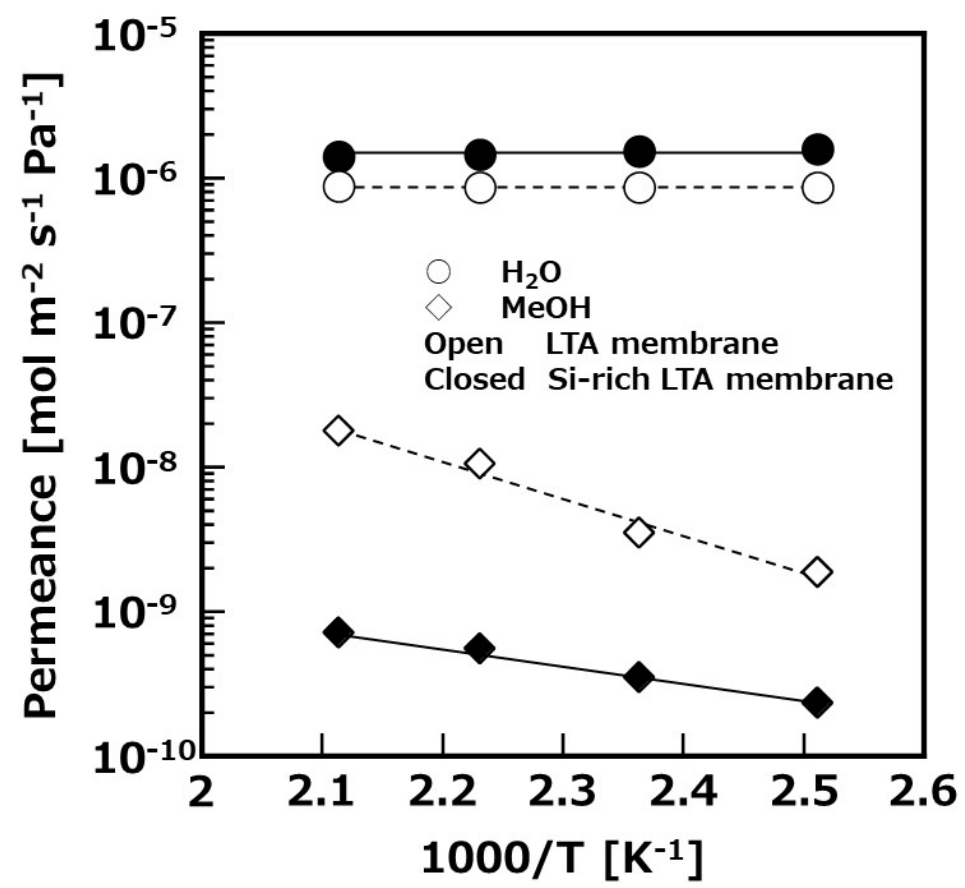

Figure 3. Temperature dependence of vapor permeation through synthesized Si-rich LTA membrane at $398-473 \mathrm{~K}$ in a $10 / 90 \mathrm{wt} \%$ vapor of $\mathrm{H}_{2} \mathrm{O} / \mathrm{MeOH}$.

Figure 4 shows the temperature dependence of $\mathrm{CO}_{2}$ conversion at $1 \mathrm{MPa}$ reaction pressure and the SV set at $200 \mathrm{~h}^{-1}$. For comparison, the results of the packed-bed reactor tests are also shown in this figure. In the results of the packed-bed reactor, the experimental and calculated conversion of $\mathrm{CO}_{2}$ were in good agreement in the temperature range 453$493 \mathrm{~K}$, therefore, the constructed simulation model was appropriate. From this result, it was considered that the concentration polarization in the radial direction of the reactor was negligible. It was experimentally clarified that both the packed-bed reactor and membrane reactor showed the maximum $\mathrm{CO}_{2}$ conversion at a reaction temperature of $473 \mathrm{~K}$. The $\mathrm{CO}_{2}$ conversion was $8 \%$ in the packed-bed reactor, while it was $20 \%$ in the membrane reactor. The thermodynamic equilibrium conversion of the packed-bed reactor and membrane reactor was calculated and compared with the experimental conversion to consider the reason that the $\mathrm{CO}_{2}$ conversion was shown maximum value at $473 \mathrm{~K}$. The equilibrium conversion of the membrane reactor was calculated on the assumption that the water molecules were permeated to be the same partial pressure of water in feed and permeate side. When the reaction temperature was higher than $473 \mathrm{~K}$, the $\mathrm{CO}_{2}$ conversion was decreased according to thermodynamic equilibrium conversion. On the other hand, the $\mathrm{CO}_{2}$ conversion was shown to have decreasing tendency because the catalyst activity 
was lower below $473 \mathrm{~K}$. From these results, we successfully demonstrated that the $\mathrm{CO}_{2}$ conversion was improved owing to the removal of water molecules from the reaction system by the membrane reactor using the developed Si-rich LTA membrane. In addition, when the selectivity of $\mathrm{H}_{2} \mathrm{O}$ /raw material $\left(\mathrm{CO}_{2}, \mathrm{CO}\right.$, and $\left.\mathrm{H}_{2}\right)$ was 300 , the experimental and calculated conversion of $\mathrm{CO}_{2}$ showed good agreement, therefore, the selectivity of the synthesized membrane was considered at least 300 . The simulation results showed that the purity of $\mathrm{MeOH}$ after vapor-liquid separation was around $50 \%$ in the packed-bed reactor, however, the purity of $\mathrm{MeOH}$ was improved to around $95 \%$ in the membrane reactor that performed reaction and separation at the same time.

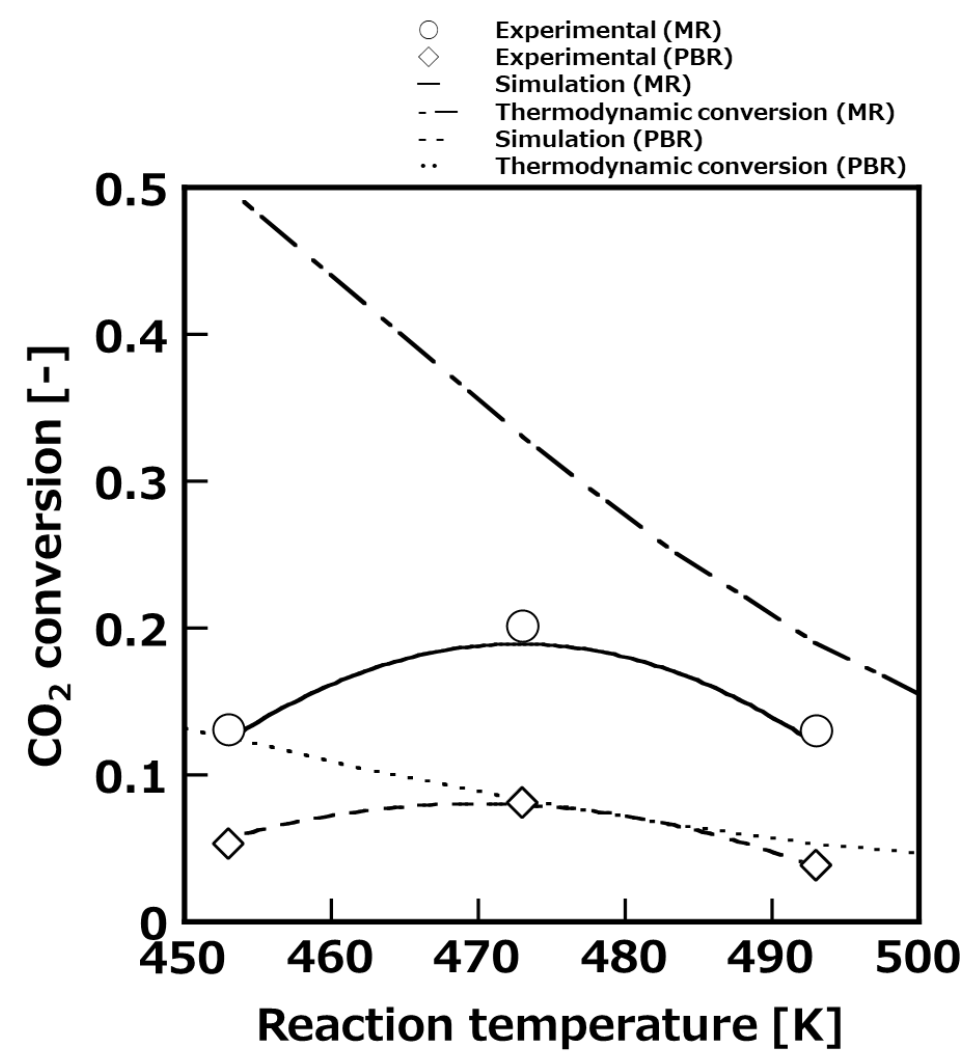

Figure 4. Temperature dependence of $\mathrm{CO}_{2}$ conversion to compare with membrane reactor (MR) and packed-bed reactor (PBR) at $1 \mathrm{MPa}$.

Figure 5 shows the influence of reaction pressure on $\mathrm{CO}_{2}$ conversion at $473 \mathrm{~K}$, which was the optimal reaction temperature resulted from Figure 4 . The SV was set at $200 \mathrm{~h}^{-1}$. In both the packed-bed reactor and membrane reactor, the $\mathrm{CO}_{2}$ conversion improved as the reaction pressure increased. The membrane reactor using Si-rich LTA membrane showed a higher conversion in all pressure ranges compared with packed-bed reactor. In particular, at a reaction pressure of $4 \mathrm{MPa}$, the $\mathrm{CO}_{2}$ conversion of the packed-bed reactor was around $20 \%$, while that of the membrane reactor was around $60 \%$. On the other hand, a similar test was performed using LTA zeolite membrane, however, the $\mathrm{CO}_{2}$ conversion was approximately $10 \%$, conversion that was approximately the same as with the packed-bed reactor. Water permselective performance of the LTA membrane was $8.7 \times 10^{-7} \mathrm{~mol} \mathrm{~m}^{-2} \mathrm{~s}^{-1} \mathrm{~Pa}^{-1}$ of $\mathrm{H}_{2} \mathrm{O}$ permeance, and around 50 of $\mathrm{H}_{2} \mathrm{O} / \mathrm{MeOH}$ selectivity at $473 \mathrm{~K}$, which was lower than those of the Si-rich LTA membrane. In the membrane reactor test using the LTA membrane, we could not increase the reaction pressure above $1 \mathrm{MPa}$, because raw materials $\left(\mathrm{H}_{2}\right.$ and $\mathrm{CO}_{2}$ ) were passing through the LTA membrane. 


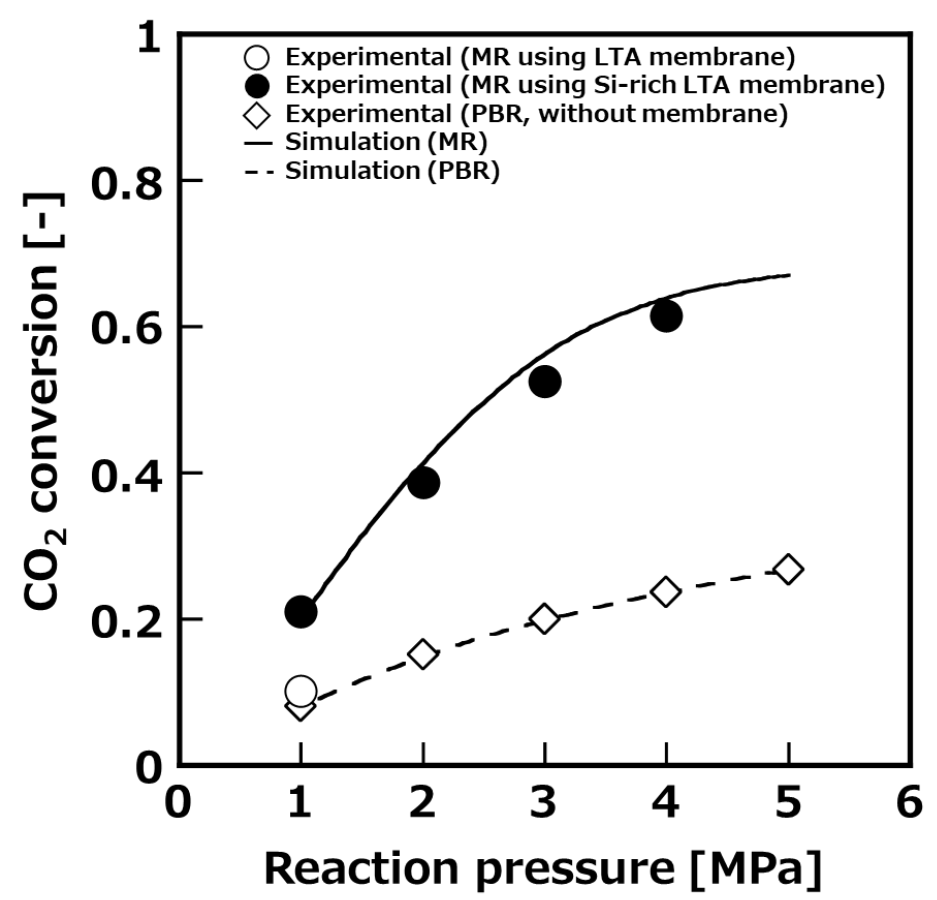

Figure 5. Pressure dependence of $\mathrm{CO}_{2}$ conversion to compare with membrane reactor (MR) and packed-bed reactor $(\mathrm{PBR})\left(\mathrm{SV}=200 \mathrm{~h}^{-1}\right)$.

Figure 6 shows the experimental and simulation results of the membrane reactor under a relatively high raw material feed rate $\left(\mathrm{SV}=1000 \mathrm{~h}^{-1}\right)$. In the simulation results, it was found that the $\mathrm{CO}_{2}$ conversion showed a maximum of around $493 \mathrm{~K}$. The membrane reactor tests were conducted at $493 \mathrm{~K}$ in the reaction pressure range $1-2 \mathrm{MPa}$. When the reaction pressures were 1 and $2 \mathrm{MPa}$, the $\mathrm{CO}_{2}$ conversion showed 8 and $18 \%$, respectively. In the case of the packed-bed reactor, those conversions were 5 and $8 \%$, respectively. Therefore, the effect of the membrane reactor could be demonstrated even with a relatively high raw material feed rate.

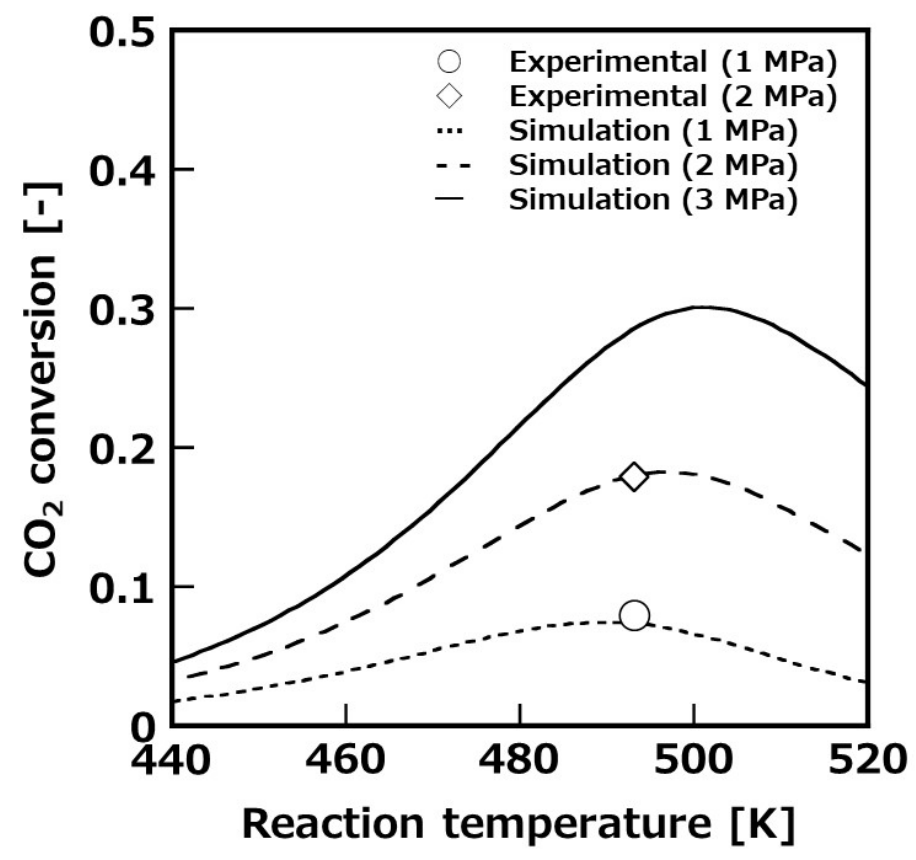

Figure 6. Experimental and simulation results of membrane reactor $\left(S V=1000 \mathrm{~h}^{-1}\right)$. 


\section{Conclusions}

We synthesized an Si-rich LTA zeolite membrane, and the membrane showed relatively high $\mathrm{H}_{2} \mathrm{O}$ permselective performance compared with a conventional LTA membrane. The methanol synthesis membrane reactor test using synthesized an Si-rich LTA membrane was conducted under the reaction conditions with SV $=200$ and $1000 \mathrm{~h}^{-1}$ and reaction temperature of 453-493 K. Higher $\mathrm{CO}_{2}$ conversion of the membrane reactor was obtained than that of conventional packed-bed reactor because $\mathrm{H}_{2} \mathrm{O}$ molecules were extracted from the reaction system. In particular, the $\mathrm{CO}_{2}$ conversion of membrane reactor achieved around $60 \%$ at $4 \mathrm{MPa}$, which was three times higher than that of the packed-bed reactor under the reaction conditions of SV $=200 \mathrm{~h}^{-1}$, and reaction temperature of $473 \mathrm{~K}$. The constructed simulation model for membrane reactor was able to reproduce the experimental results in this study. For practical use, it is necessary to increase the effective membrane area of the Si-rich LTA membrane, and develop an optimal structure of membrane reactor module for methanol synthesis.

Author Contributions: Conceptualization, K.Y.; methodology, M.S. and K.Y.; formal analysis, B.L. and H.R.L.; investigation, M.S. and K.Y.; data curation, M.S.; writing-original draft preparation, M.S.; writing-review and editing, K.Y., H.K., and S.-i.N.; supervision, H.K. and S.-i.N.; project administration, Y.Y.; resources, N.S. and Y.M.; funding acquisition, K.Y. All authors have read and agreed to the published version of the manuscript.

Funding: This study was financially supported by New Energy and Industrial Technology Development Organization (NEDO) as a "Development of next-generation thermal power generation technologies / Development of basic technologies for next-generation thermal power generation / Development of $\mathrm{CO}_{2}$ utilization technology project".

Institutional Review Board Statement: Not applicable.

Informed Consent Statement: Not applicable.

Data Availability Statement: Not applicable.

Conflicts of Interest: The authors declare no conflict of interest.

\section{References}

1. Struis, R.P.W.J.; Stucki, S.; Wiedorn, M. A membrane reactor for methanol synthesis. J. Membr. Sci. 1996, 113, 93-100. [CrossRef]

2. Struis, R.P.W.J.; Stucki, S. Verification of the membrane reactor concept for the methanol synthesis. Appl. Catal. A 2001, 216, 117-129. [CrossRef]

3. Allemand, M.; Martin, M.H.; Reyter, D.; Roué, L.; Guay, D.; Andrei, C.; Botton, G. Synthesis of Cu-Pd alloy thin film by co-electrodeposition. Electrochem. Acta. 2011, 56, 7397-7403. [CrossRef]

4. Seshimo, M.; Ozawa, M.; Sone, M.; Sakurai, M.; Kameyama, H. Fabrication of a novel Pd/ $\gamma$-alumina graded membrane by electroless plating on nanoporous $\gamma$-alumina. J. Membr. Sci. 2008, 324, 181-187. [CrossRef]

5. Yoshimune, M.; Haraya, K. Flexible carbon hollow fiber membranes derived from sulfonate poly(phenylene oxide). Sep. Purif. Technol. 2010, 75, 193-197. [CrossRef]

6. Itta, A.K.; Tseng, H.-H.; Wey, M.-Y. Fabrication and characterization of PPO/PVP blend carbon molecular sieve membranes for $\mathrm{H}_{2} / \mathrm{N}_{2}$ and $\mathrm{H}_{2} / \mathrm{CH}_{4}$ separation. J. Membr. Sci. 2011, 372, 387-395. [CrossRef]

7. Da Costa, J.D.; Lu, G.; Rudolph, V.; Lin, Y. Novel molecular sieve silica (MSS) membranes: Characterisation and permeation of single-step and two-step sol-gel membranes. J. Membr. Sci. 2002, 198, 9-21. [CrossRef]

8. Kanezashi, M.; Shioda, T.; Gunji, T.; Tsuru, T. Gas permeation properties of silica membranes with uniform pore size derived from polyhedral oligomeric silsesquioxane. AIChE J. 2012, 58, 1733-1743. [CrossRef]

9. Seshimo, M.; Akamatsu, K.; Furuta, S.; Nakao, S.-I. Comparative study on the influence of toluene and methylcyclohexane on the performance of dimethoxydiphenylsilane-derived silica membranes prepared by chemical vapor deposition. Sep. Purif. Technol. 2015, 140, 1-5. [CrossRef]

10. Coronas, J.; Noble, R.D.; Falconer, J.L. Separation of $\mathrm{C}_{4}$ and $\mathrm{C}_{6}$ isomers in ZSM-5 tubular membranes. Ind. Eng. Chem. Res. 1998, 37, 166-176. [CrossRef]

11. Krishna, R.; Paschek, D. Permeation of hexane isomers across ZSM-5 zeolite membranes. Ind. Eng. Chem. Res. 2000, 39, 2618-2622. [CrossRef]

12. Matsufuji, T. Separation of butane and xylene isomers with MFI-type zeolitic membrane synthesized by a vapor-phase transport method. J. Membr. Sci. 2000, 178, 25-34. [CrossRef] 
13. Xomeritakis, G.; Lai, Z.; Tsapatsis, M. Separation of xylene isomer vapors with oriented MFI membranes made by seeded growth. Ind. Eng. Chem. Res. 2001, 40, 544-552. [CrossRef]

14. Okamoto, K.-I.; Kita, H.; Horii, A.K.; Kondo, K.T. Zeolite NaA Membrane: Preparation, Single-Gas Permeation, and Pervaporation and Vapor Permeation of Water/Organic Liquid Mixtures. Ind. Eng. Chem. Res. 2001, 40, 163-175. [CrossRef]

15. Kondo, M.; Yamamura, T.; Yukitake, T.; Matsuo, Y.; Kita, H.; Okamoto, K.-I. IPA purification for lens cleaning by vapor permeation using zeolite membrane. Sep. Purif. Technol. 2003, 32, 191-198. [CrossRef]

16. Cho, C.H.; Oh, K.Y.; Yeo, J.G.; Kim, S.K.; Lee, Y.M. Synthesis, ethanol dehydration and thermal stability of NaA zeolite/alumina composite membranes with narrow non-zeolitic pores and thin intermediate layer. J. Membr. Sci. 2010, 364, 138-148. [CrossRef]

17. Zhou, R.; Hu, Z.; Hu, N.; Duan, L.; Chen, X.; Kita, H. Preparation and microstructural analysis of high-performance mordenite membranes in fluoride media. Microporous Mesoporous Mater. 2012, 156, 166-170. [CrossRef]

18. Li, Y.; Zhu, M.; Hu, N.; Zhang, F.; Wu, T.; Chen, X.; Kita, H. Scale-up of high performance mordenite membranes for dehydration of water-acetic acid mixtures. J. Membr. Sci. 2018, 564, 174-183. [CrossRef]

19. Hasegawa, Y.; Hotta, H.; Sato, K.; Nagase, T.; Mizukami, F. Preparation of novel chabazite (CHA)-type zeolite layer on porous $\alpha-\mathrm{Al}_{2} \mathrm{O}_{3}$ tube using template-free solution. J. Membr. Sci. 2010, 347, 193-196. [CrossRef]

20. Jiang, J.; Wang, X.; Zhang, Y.; Liu, D.; Gu, X. Fabrication of pure-phase CHA zeolite membranes with ball-milled seeds at low K ${ }^{+}$ concentration. Microporous Mesoporous Mater. 2015, 215, 98-108. [CrossRef]

21. Itho, N.; Ishida, J.; Sato, T.; Hasegawa, Y. Vapor phase esterification using a CHA type of zeolite membrane. Catal. Today 2016, 268, 79-84. [CrossRef]

22. Sawamura, K.-I.; Izumi, T.; Kawasaki, K.; Daikohara, S.; Sekine, Y.; Kikuchi, E.; Matsukata, M.; Ohsuna, T.; Takada, M. Cover Picture: Reverse-Selective Microporous Membrane for Gas Separation (Chem. Asian J. 7/2009). Chem. Asian J. $2009,4,1015$. [CrossRef]

23. Sawamura, K.; Shirai, T.; Takada, M.; Sekine, Y.; Kikuchi, E.; Matsukata, M. Selective permeation and separation of steam from water-methanol-hydrogen gas mixtures through mordenite membrane. Catal. Today 2008, 132, 182-187. [CrossRef]

24. Raso, R.; Tovar, M.; Lasobras, J.; Herguido, J.; Kumakiri, I.; Araki, S.; Menendez, M. Zeolite membranes: Comparison in the separation of $\mathrm{H}_{2} \mathrm{O} / \mathrm{H}_{2} / \mathrm{CO}_{2}$ mixtures and test of a reactor for $\mathrm{CO}_{2}$ hydrogenation to methanol. Catal. Today 2021, 364, 270-275. [CrossRef]

25. Liu, B.; Kita, H.; Yogo, K. Preparation of Si-rich LTA zeolite membrane using organic template-free solution for methanol dehydration. Sep. Purif. Technol. 2020, 239, 116533. [CrossRef]

26. Conato, M.T.; Oleksiak, M.D.; McGrail, B.P.; Motkuri, R.K.; Rimer, J.D. Framework stabilization of Si-rich LTA zeolite prepared in organic-free media. Chem. Commun. 2015, 51, 269. [CrossRef]

27. Graaf, G.H.; Sijtsema, P.J.J.M.; Stamhuis, E.J.; Joosten, G.E.H. Chemical equilibria in methanol synthesis. Chem. Eng. Sci. 1986, 41, 2883-2890. [CrossRef]

28. Graaf, G.H.; Stamhuis, E.J.; Beenackers, A.A.C.M. Kinetics of low-pressure methanol synthesis. Chem. Eng. Sci. 1988, 43, 3185-3195. [CrossRef]

29. Graaf, G.H.; Scholtens, H.; Stamhuis, E.J.; Beenackers, A.A.C.M. Intra-particle diffusion limitations in low-pressure methanol synthesis. Chem. Eng. Sci. 1990, 45, 773-783. [CrossRef] 